\title{
DAMPAK RIBA TERHADAP SOSIAL EKONOMI PEDAGANG PASAR; STUDI PEDAGANG PASAR SEMULI RAYA LAMPUNG UTARA
}

\author{
Aye Sudarto \\ IAI Agus Salim Metro Lampung \\ e-mail: ayesudarto18@gmail.com
}

\begin{abstract}
In economic activity, capital is the most crucial thing. Obtaining that basic financial factor can be done independently or through submitting loans from other parties (investors). Until now, the lower class still have difficulty dealing with financial institutions, related to certain requirements. Consequently, they choose the easiest way, without any complicated pre-requirements, commonly known as loan sharks. This research is qualitative field research using descriptive analysis. The findings reveal that the reason these traders make capital submissions to moneylenders is because the process of borrowing money is fast and easy. They do not have to have valuables as collateral. In addition, the amount of money is moderately small. Relying on trust, they can immediately receive the loans. The rent-seeking among the community, practically, has a lot of negative impacts on the community's economy. The rent-seeking carried out in Semuli Raya, Abung Semuli Subdistrict, has caused the people's economy, especially the market traders, to be very disturbed both for their daily needs and even on the education of their children.
\end{abstract}

Keywords: usury; market trader; money lender (rentenir)

\section{Pendahuluan}

Kegiatan ekonomi adalah kegiatan seseorang, suatu perusahaan atau suatu masyarakat untuk memproduksi, mengkonsumsi (menggunakan) barang dan jasa. ${ }^{1}$ Modal menjadi hal yang penting dalam kegiatan ekonomi. Untuk mendapatkan barang modal dapat dilakukan dengan cara mandiri maupun pengajuan pinjaman pihak lain atau pemodal. Sampai saat ini, masyarakat kelas bawah masih kesulitan berhubungan dengan lembaga keuangan karena terkait dengan persyaratan. Jalan yang dipilih pada akhirnya adalah memilih yang paling mudah dan tanpa syarat bermacam-macam yang biasa dikenal dengan plecit (rentenir).

Berhubungan dengan sumber pembiayaan informal seringkali membuat terlena dan menjadi pilihan yang menarik karena faktor kemudahan mendapatkan dana secara cepat tanpa birokrasi dengan asas saling percaya meskipun berbunga tinggi. ${ }^{2}$ Tingginya kebutuhan masyarakat atas dana atau pembiayaan terutama untuk modal usaha membuat rentenir masih tumbuh pesat. Selain karena mudah mencairkan dananya, banyaknya prosedur perbankan

\footnotetext{
1 Zakira Ibrahim, "Pengertian Kegiatan Ekonomi: Definisi dan Jenis" dalam https://www.pengertiandefinisi.com/pengertian-kegiatan-ekonomi-definisi-dan-jenis/ diakses pada 20 Oktober 2020.

2 Fersia Amalia, "Uang, Lembaga Keuangan dan Lembaga Keuangan Informal” dalam https://www.google.com/amp/s/fersiamalia.wordpress.com/20111/11/28/uang-lembaga-keuangan-dan-lembagakeuangan-informal/amp diakses pada 31 Oktober 2019.
} 
menjadi faktor utama yang membuat masyarakat tidak mengandalkan lembaga keuangan dalam hal pembiayaan. ${ }^{3}$

Di samping kemudahan dalam mendapatkan dana atau pembiayaan dari rentenir, terdapat sisi lain yang sebenarnya bisa memberatkan masyarakat, yaitu besarnya bunga (riba) yang harus dibayarkan kepada rentenir. Padahal dana yang didapatkan oleh pedagang pasar tradisional Semuli Raya Abung Semuli Lampung Utara melalui sistem rente ini pada dasarnya digunakan sebagai suntikan modal untuk usaha dagangnya. Ironisnya, apabila pedagang mendapatkan tambahan modal, maka mereka harusnya dapat lebih banyak menambah barang dagangannya sehingga dapat memberikan tambahan pendapatan bagi mereka. Tetapi yang terjadi justru sebaliknya, karena tingginya bunga pinjaman yang harus dibayarkan kepada rentenir dan jangka waktu yang relatif lebih pendek dalam membayar angsuran pinjaman yang umumnya dua sampai tiga kali seminggu membuat pedagang sulit berkembang dan cenderung merugi.

Sejatinya pasar tradisional Semuli Raya telah memberikan kontribusi yang signifikan kepada masyarakat sekitar dalam memenuhi kebutuhan sehari-hari dengan harga yang terjangkau. Konsumen dengan mudah dapat memilih dan menawar untuk mendapatkan barang kebutuhannya. Tetapi kondisi ini mungkin akan hilang manakala para pedagang tidak lagi mampu mempertahankan usaha dagangannya dan bersamaan dengan itu, mereka terbebani dengan hutang kepada rentenir. Bukan keuntungan yang mereka dapatkan tetapi kerugian yang menggerus akibat bunga tinggi dari rentenir. Kondisi inilah yang terjadi pada pedagang di pasar tradisional Semuli Raya yang kemudian menjadi perhatian penulis untuk melihat dampak dari praktik rentenir terhadap sosial ekonomi pedagang pasar tradisional Semuli Raya Abung Semuli Lampung Utara.

\section{Metode Penelitian}

Penelitian ini merupakan penelitian lapangan (field research). Penelitian lapangan adalah pencarian data di lapangan (lokasi penelitian) karena penelitian yang dilakukan menyangkut dengan persoalan atau kenyataan dalam kehidupan nyata bukan pemikiran abstrak yang terdapat dalam teks-teks atau dokumen-dokumen tertulis atau terekam. ${ }^{4}$ Penelitian kualitatif adalah suatu proses penelitian yang memberikan pemahaman berdasarkan metodelogi yang bersifat menyelidiki suatu fenomena sosial yang ada di dalam masyarakat. ${ }^{5}$ Pendekatan kualitatif merupakan suatu pendekatan penelitian yang hasil penelitiannya tidak diolah dalam bentuk kalkulasi angka-angka, melainkan dengan cara menyampaikan pemikiran atau wawancara peneliti terkait dengan data yang diambil dari subjek yang diteliti. ${ }^{6}$

\footnotetext{
3 Elvidari Sinamora, "Rentenir Akan Tumbuh Pesat" dalam http://medanbisnisdaily.com/news/read/2014/02/05/77027/rentenir_akan_tumbuh_pesat/\#VEPc6_I dWil diakses pada 10 Oktober 2019.

${ }^{4}$ Nasir Budiman, dkk, Pedoman Penulisan Karya Ilmiah (Banda Aceh: Ar-Raniry, 2004), 23.

5 Juliansyah Noor, Metodelogi Penelitian: Skripsi, Tesis, Disertasi, dan Karya Ilmiah, (Jakarta: Kencana Prenada Media Group, 2011), 42.

${ }^{6}$ Husen Umar, Metode Riset Komunikasi Organisasi (Jakarta: Gramedia Pustaka Utama, 2005), 3.
} 


\section{Pengertian dan Sejarah Riba}

Riba secara bahasa bermakna tambahan, tumbuh dan membesar. Dari beberapa definisi riba yang ada terdapat sebuah ketegasan bahwa riba itu adalah pengambilan tambahan, baik dalam transaksi jual beli maupun pinjam-meminjam secara batil. ${ }^{7}$ Riba dalam kehidupan keseharian juga dikenal dengan rente. Rentenir adalah seseorang yang melakukan kegiatan peminjaman uang atau modal. ${ }^{8}$ Renten atau kegiatan renten merupakan suatu aktivitas di mana seseorang meminjamkan uang dengan bunga yang berlipat-lipat yang memungkinkan bunga tersebut melebihi hutang pokoknya jika cicilannya terlambat. ${ }^{9}$ Wayne A. M. Visser Alastair McIntosh dalam "A Short Review of the Historical Critique of Usury" menjelaskan bahwa praktik riba setidaknya sudah berjalan sejak empat ribu tahun yang lalu dan selama sejarah itu pula, praktik ini dikutuk, dilarang, dihina, dan dihindari. ${ }^{10}$

Rentenir secara harfiah berasal dari kata rente yang artinya renten, bunga uang. Kata ini tidak jauh berbeda dengan makna riba yang secara bahasa berarti ziyädah (tambahan) baik dalam transaksi jual beli maupun pinjam meminjam. Institusi yang memperoleh profit melalui penarikan bunga disebut sebagai lembaga rente, seperti bank, koperasi dan lembaga perkreditan lainnya. Sedangkan individu yang memperoleh profit melalui penarikan bunga disebut dengan rentenir. ${ }^{11}$

Praktik yang dilakukan oleh seorang rentenir yang memberikan bunga kepada nasabahnya mengandung unsur riba. Hakikat pelarangan riba dalam Islam adalah suatu penolakan terhadap resiko finansial tambah yang ditetapkan dalam transaksi uang atau modal maupun jual beli yang dibedakan kepada satu pihak saja sedangkan yang lainnya dijamin keuntungannya. Bunga pinjaman uang dan barang-barang dalam segala bentuk dan macamnya, baik untuk tujuan produktif atau konsumtif dengan tingkat bunga yang tinggi atau rendah, dan dalam jangka waktu panjang maupun pendek adalah termasuk riba. ${ }^{12}$

Pengharaman riba maksudnya adalah pengharaman apa yang disebut dengan bunga, yaitu sesuatu yang merupakan azas penghubung ekonomi kapitalis. Bunga atas pinjaman baik jumlahnya sedikit atau banyak adalah haram. Termasuk juga di dalamnya terdapat hukum mengatur tentang keharaman dalam melakukan riba. Keharaman ini sebagaimana keharaman dalam meminum khamr tidak dilakukan sekaligus, namun secara berangsur-angsur. Dalam alQuran surat al-Rum ayat 39 yang membahas tentang riba, belum terlihat dalam ayat ini adanya keharaman melakukan riba, namun sekedar menggambarkan bahwa riba yang dalam sangkaan orang menghasilkan penambahan harta dalam pandangan Allah tidak benar. Akan tetapi zakatlah yang mendatangkan pahala yang berlipat ganda. Kata zakat dalam ayat ini bukanlah zakat yang diwajibkan melainkan sedekah biasa mengingat ayat ini turun pada

\footnotetext{
${ }^{7}$ M. Nadrotuzaman Hosen dan AM. Hasan Ali, Kamus Populer Keuangan dan Ekonomi Syariah (Jakarta: PKES Publising, 2008), 81.

8 Ilas Korwadi Siboro, “Analisis Terhadap Fungsi Pinjaman Berbunga dalam Masyarakat Rokan Hilir Kecamatan Bagan Sinembah Desa Bagan Batu”, Jom Fisip, Volume 2, Nomor 1 (2015), 1.

${ }^{9}$ Ibid.

10 Roman Rendusara, "Rentenir dan Lemahnya Hukum Perbankan Indonesia" dalam http://hukum.kompansiana.com/2012/07/20/rentenir-dan-lemahnya-hukum-perbankan-indoneisa-472787.html diakses pada 5 Oktober 2019.

${ }^{11}$ Muhammad Khoiri, "Dampak Pinjaman Rentenir Terhadap Pendapatan Pedagang Pasar Tradsional di Pasar Pagi Pulo Brayan Bengkel” (Skripsi--UIN Sumatera Utara Medan, 2018), 37.

12 Faried Wijaya, dkk, Lembaga-Lembaga Keuangan dan Bank (Yogyakarta: BPFEY, 1999), 413.
} 
periode Makkah sedangkan kewajiban zakat baru ditetapkan setelah Nabi Muhammad hijrah ke Madinah, tepatnya pada tahun ke-2 $\mathrm{H}$.

Konsep rente pertama kali dikembangkan oleh pakar ekonomi klasik David Ricardo, ia mengamati bahwa tingkat kesuburan tanah berbeda-beda. Petani yang memiliki tanah yang lebih subur bisa beroperasi dengan biaya rata-rata lebih rendah. Sedangkan petani yang memiliki lahan kurang subur beroperasi rata-rata dengan biaya yang lebih tinggi. Perbedaan dalam tingkat kesuburan tanah berpengaruh terhadap sewa tanah. Adapun yang disebut sewa tanah oleh Ricardo adalah perbedaan antara penerimaan yang diterima petani yang memiliki tanah lebih subur dengan penerimaan yang diterima oleh petani marjinal. Yaitu petani yang menggarap tanah paling tidak subur tetapi tetap bisa beroperasi di mana penerimaannya hanya cukup untuk menutup ongkos produksi. Ini berarti bahwa sewa tanah terkait erat dengan tingkat kesuburannya, dan pemilik tanah paling subur akan menikmati sewa tanah tinggi. ${ }^{13}$ Sewa ekonomi atau rente suatu faktor produksi tertentu adalah kelebihan pembayaran atas biaya minimum yang diperlukan untuk tetap mengkonsumsi faktor produksi tersebut. Segala bentuk eksesif (super normal) yang berbuhubungan dengan struktur pasar barang dan jasa yang mengerah ke monopoli disebut rente. ${ }^{14}$

Dale W Adam menyebutkan rentenir adalah individu yang memberikan kredit jangka pendek, tidak menggunakan jaminan yang pasti, bunga relatif tinggi dan selalu berupaya melanggengkan kredit dengan nasabah. ${ }^{15}$ Menurut Kamus Besar Bahasa Indonesia rentenir adalah orang yang memberikan nafkah dan membungakan uang (tukang riba; pelepas uang; Lintah darat). ${ }^{16}$

Rentenir adalah pemberi pinjaman uang (kreditur) dengan bunga sekitar 10-30 persen per bulan dalam kondisi perekonomian normal dengan rata-rata bunga pinjaman bank umum kurang lebih 1-2 persen per bulan. Plafon pinjaman yang diberikan biasanya antara Rp. 50.000,- sampai dengan Rp. 1.000.000,-. Target peminjam (debitur) mereka biasanya orangorang dengan ekonomi lemah yang tinggal di kota atau pinggiran kota, seperti buruh kecil, pegawai kecil dan perajin kecil atau dengan istilah lain masyarakat yang kurang mampu dari segi ekonomi. ${ }^{17}$ Pendapat yang rajih (kuat), sedikit maupun banyak bunga itu termasuk rente atau riba. ${ }^{18}$ Kesimpulan ini diambil berdasarkan pada firman Allah dalam al-Quran surat alBaqarah ayat 278 .

Afzalurrahman dalam Muhammad dan Sholikhul Hadi, memberikan pedoman bahwa yang dikatakan riba (bunga) di dalamnya terdapat tiga unsur berikut: ${ }^{19}$

1. Kelebihan dari pokok pinjaman.

2. Kelebihan pembayaran itu sebagai imbalan tempo pembayaran.

3. Sejumlah tambahan itu diisyaratkan dalam transaksi.

\footnotetext{
${ }^{13}$ Deliarnov, Ekonomi Politik (Jakarta: Erlangga, 2006), 59.

${ }^{14}$ Ibid., 62.

15 Khudzaifah Dimyati, "Profil Praktik Pelepasan Uang (Rentenir) dalam Masyarakat Transisi” (Tesis-Universitas Diponegara, 1997), 16.

${ }^{16}$ Departemen Pendidikan dan Kebudayaan, Kamus Besar Bahasa Indonesia (Jakarta: Balai Pustaka, 1995$), 457$.

17 Juwita Fajar Hari, "Dampak Pinjaman Kredit terhadap Kesejahteraan Pedagang Pasar Tradisional dalam Tinjauan Ekonomi Islam" (Skripsi--IAIN ImamBonjol, 2009), 24.

18 Aye Sudarto, Etika Bisnis Islam (Metro: Purnama Jaya, 2019), 137.

${ }^{19}$ Sasli Rais, Pegadaian Syariah: Konsep dan Sistem Operasinal (Jakarta: UI-Press, 2006), 50.
} 


\section{Pasar dalam Islam}

Pasar merupakan pertemuan seluruh pembeli dan potensial atas tawaran pasar tertentu. ${ }^{20}$ Pasar selama ini sudah menyatu dan memiliki tempat paling penting dalam kehidupan masyarakat sehari-hari. Bagi masyarakat, pasar bukan hanya tempat bertemunya antara penjual dan pembeli tetapi juga sebagai wadah untuk berinteraksi sosial. ${ }^{21}$

Pasar adalah tempat bertemunya pembeli dan penjual yang melakukan transaksi atas suatu produk tertentu. Sedangkan dalam manajemen pasar, konsep pasar terdiri atas semua pelanggan potensial yang mempunyai kebutuhan atau keinginan tertentu yang mungkin bersedia dan mampu melibatkan diri dalam suatu pertukaran guna memuaskan kebutuhan atau keinginan tersebut. ${ }^{22}$ Pertemuan antara orang yang menjual dan orang yang mau membeli suatu barang atau jasa tertentu dengan harga tertentu. Jika kedua belah pihak tersebut dipertemukan maka akan terjadi transaksi jual beli. Faktor penting yang dapat mempertemukan mereka adalah harga yang terbentuk pasar dalam interaksi antara penjual dan pembeli tersebut ${ }^{23}$.

Dalam manajemen pemasaran, konsep pasar terdiri atas semua pelanggan potensial yang mempunyai kebutuhan atau keinginan tertentu yang mungkin bersedia dan mampu melibatkan diri dalam suatu pertukaran guna memuaskan kebutuhan dan keinginan. ${ }^{24} \mathrm{Al}-$ Quran juga menjelaskan bahwa orang yang berdagang itu tidak akan kehilangan kemuliaan dan kekharismaannya bila melakukan kegiatan ekonomi dalam pasar, ${ }^{25}$ sesuai firman Allah dalam surat al-Furqan ayat 20 .

Pasar memiliki fungsi sebagai penentu nilai suatu barang, penentu jumlah produksi, mendistribusikan produk, melakukan pembatasan harga dan menyediakan barang dan jasa untuk jangka panjang. Pasar sebagai tempat terjadinya transaksi jual beli, merupakan fasilitas publik yang sangat penting bagi perekonomian suatu daerah dan juga menjadi barometer bagi tingkat pertumbuhan ekonomi masyarakat. ${ }^{26}$ Dalam Islam harus diperhatikan perilaku dan etika seorang penjual yang didasarkan dengan prinsip-prinsip pasar yang efisien, yaitu: ${ }^{27}$

1. Prinsip suka sama suka

Islam menggariskan setiap perniagaan dilandasi dengan asas suka sama suka, sebagaimana dalam firman Allah dalam surat al-Nisa ayat 29.

2. Prinsip penetapan harga dan keuntungan

Dalam Islam prinsip harga, ditentukan oleh keseimbangan permintaan dan penawaran, jadi harga ditentukan oleh kemampuan penjual untuk menyediakan dan mendapatkan harga tersebut dari penjual. ${ }^{28}$ Sebagaiman hadis Nabi yang menyatakan

\footnotetext{
${ }^{20}$ Philip Kotler, Manajemen Pemasaran, terj. Benyamin Molan, jilid 1 (Jakarta: PT. Intan Sejati Klaten, 2005), 157.

${ }^{21}$ Muhammad Aziz Hakim, Menguasai Pasar Mengeruk Untung (Jakarta: PT. Krisna Persada, 2005), 4.

22 Akhmad Mujahidin, Ekonomi Islam: Sejarah, Konsep, Instrument, Negara dan Pasar (Jakarta: Rajawali Pers, 2014), 141.

${ }^{23}$ Gilarso, Pengantar Ilmu Ekonomi (Yogyakarta: t.p., 1991), 64.

${ }^{24}$ Akhmad Mujahidin, “Ekonomi Islam, 141.

${ }^{25}$ Mustafa Edwin Nasution, Pengenalan Eksklusif Ekonomi Islam (Jakarta: Kencana, 2007), 158.

${ }^{26}$ Akhmad Mujahidin, Ekonomi Islam, 142.

${ }^{27}$ Lukmanul Hakim, Prinsip-Prinsip Ekonomi Islam (Jakarta: Erlangga, 2012), 166.

${ }^{28}$ Aye Sudarto, Peradaban Ekonomi Islam (Metro: Purnama Jaya, 2018), 15-16.
} 
bahwa sesungguhnya Allah lah yang menentukan harga, yang menahan, yang melapangkan, dan yang memberi reziki. (riwayat al-Daraini)

3. Prinsip tidak merugikan orang lain

Islam mengharamkan setiap perniagaan yang dapat meresahkan atau merugikan orang lain, sebagaimana dalm firman Allah dalam surat al-Hujurat ayat 10.

Islam menempatkan pasar pada kedudukan yang penting dalam perekonomian. Praktik ekonomi pada masa Rasulullah SAW dan al-Khulafā al-Rāshidūn menunjukkan adanya peranan pasar yang besar. Rasulullah sangat menghargai harga yang dibentuk oleh pasar sebagai harga yang adil. Beliau menolak adanya suatu price intervention seandainya perubahan harga terjadi karena mekanisme pasar yang wajar. Namun, pasar di sini mengharuskan adanya moralitas, antara lain persaingan yang sehat (fair play), kejujuran (honesty), keterbukaan (transparancy) dan keadilan (justice). Jika nilai-nilai ini telah ditegakkan, maka tidak ada alasan untuk menolak harga pasar. ${ }^{29}$

Pasar memegang peranan penting dalam perekonomian masyarakat muslim pada masa Rasulullah SAW dan al-Khulafā al-Rāshidūn. Bahkan, Rasulullah SAW sendiri pada awalnya adalah seorang pebisnis, demikian pula al-Khulafā al-Rāshidūn dan kebanyakan sahabat. Pada usia 7 tahun, Muhammad diajak oleh pamannya Abu Thalib berdagang ke negeri Syam. Kemudian sejalan dengan usianya yang semakin dewasa, Muhammad semakin giat berdagang, baik dengan modal sendiri ataupun bermitra dengan orang lain. Penghargaan Islam terhadap mekanisme pasar berdasar pada ketentuan Allah bahwa perniagaan harus dilakukan secara baik dengan rasa suka sama suka (goodwill), seperti yang termaktub dalam al-Quran surat al-Nisa ayat 29.

\section{Pendapatan dalam Konsep Ekonomi Islam}

Dalam kamus besar bahasa Indonesia pendapatan adalah hasil kerja atau usaha. ${ }^{30}$ Pendapatan seseorang juga dapat didefinisikan sebagai banyaknya penerimaan yang dinilai dengan satuan mata uang yang dapat dihasilkan seseorang atau suatu bangsa dalam periode tertentu. Rekso Prayitno mendefinisikan pendapatan (revenue) sebagai total penerimaan yang diperoleh pada periode tertentu. ${ }^{31}$ Dapat dipahami bahwa pendapatan adalah sebagai jumlah penghasilan yang diterima oleh para anggota masyarakat dalam jangka waktu tertentu sebagai balas jasa atau faktor-faktor produksi yang telah disumbangkan.

Dalam perspektif ekonomi, pendapatan merupakan suatu hasil yang diperoleh dari kegiatan ekonomi dengan mengorbankan suatu barang atau jasa. Barang atau jasa yang ditawarkan akan berkurang manfaat atau nilainya dan akan menghasilkan sesuatu yang disebut pendapatan. Pendapatan merupakan kenaikan kotor atau garis dalam modal pemilik yang dihasilkan dari penjualan barang dagangan, pelayanan jasa kepada klien, penyewaan harta, peminjaman uang dan semua kegiatan yang bertujuan untuk memperoleh penghasilan. ${ }^{32}$ Dalam ekonomi Islam, kita diperbolehkan mencari rezeki di manapun selagi tidak mengganggu kepentingan orang lain dan dengan cara yang halal. Manusia dianjurkan mencari

\footnotetext{
${ }^{29}$ Aye Sudarto, Etika Bisnis Islam, 137.

${ }^{30}$ https://kbbi.web.id/ diakses pada 10 Oktober 2019.

${ }^{31}$ Reksoprayitno, Sistem Ekonomi dan Demokrasi Ekonomi (Jakarta: Bina Grafika, 2004), 79.

32 C. Rollin Niswonger, dkk, Prinsip-Prinsip Akuntansi, terj. Alfonsus Sirait, jilid 1 (Jakarta: Erlangga, 1992), 56-57.
} 
nafkah di manapun di seluruh muka bumi, seperti yang dijelaskan oleh Allah dalam surat alJumu'ah ayat 10. Ayat ini menjelaskan bahwa setelah kita menunaikan kewajiban kita terhadap Allah, maka kita diperbolehkan mencari rezeki di manapun.

Dalam kaidah fikih dikatakan bahwa semua kegiatan muamalah hukumnya halal, sampai ada dalil yang melarangnya. Jadi, selama tidak ada larangan dan tidak melanggar hukum Islam, kita diperbolehkan mencari rezeki di manapun termasuk menjadi pedagang tradisional. Islam juga menjelaskan bahwa pendapatan diperoleh bukan semata-mata karena usaha, melainkan merupakan rezeki yang dititipkan, seperti firman Allah pada surat Saba' ayat 39. Ayat ini menjelaskan bahwa segala sesuatu mengenai rezeki telah diatur oleh Allah, Dia lah yang memerikan rezeki, menambah ataupun menguranginya. Manusia hanya bisa berusaha, apapun penghasilan yang kita dapatkan hendaknya disyukuri. Ayat ini juga menerangkan bahwa pada harta yang kita peroleh terdapat rezeki orang lain di dalamnya. Maka dianjurkan untuk menafkahkan harta di jalan Allah dan Allah berjanji akan mengganti rezeki tersebut dalam bentuk yang tidak diduga.

\section{Profil Singkat Pasar Semuli Raya}

Desa Semuli Raya memiliki sebuah pasar tradisional. Pasar ini milik pemerintah daerah setempat yang dikelola oleh dinas pasar. Luas Pasar Semuli Raya saat ini sekiar $20.000 \mathrm{~m} 2$ dengan pedagang mukim sekitar 100 orang, sisanya adalah pedagang pendatang. Pasar ini buka setiap hari, namun untuk pasar besar tiap hari Senin dan Jumat, sedangkan pasar kecil atau pasar sayur setiap hari Rabu. Komoditas yang dijual di pasar ini sangat beragam, mulai alat elektronik, sembako, bahan bangunan, pakaian dan sepatu sampai sayur-sayuran serta ikan laut dan tawar. Umumnya pedagang kain dan ikan berasal dari luar daerah, seperti Candimas, bahkan ada yang berasal dari luar kabupaten, yaitu dari Candirejo Lampung Tengah dan Tulang Bawang, sedangkan untuk pedagang sayuran dan makanan siap saji berasal dari desa dan kecamatan sekitar pasar.

Menurut penuturan dari tetua kampung dan beberapa catatan sejarah, bahwa pasar Semuli Raya berdiri sekitar tahun 1980, pendirian tersebut atas prakarsa dinas Transkimau. Saat pertama berdiri pasar ini hanya terdiri dari beberapa lapak dagang sayuran dan buka setiap satu minggu sekali. Pada awalnya pendirian pasar ini bertujuan mempermudah akses jual beli barang dan belanja bagi masyarakat desa Semuli Raya. ${ }^{33}$

Menurut $\mathrm{Ali}^{34}$ selaku tetua desa Semuli Raya, bahwa dahulu pasar terdekat yang bisa dijangkau untuk belanja maupun jualan adalah pasar Bumi Restu yang memiliki jarak 8 km, sedangkan pasar lain adalah pasar Tatakarya dan Ujung Batu yang memiliki jarak $20 \mathrm{~km}$. Alterntif lain yaitu pasar Dayaitoh atau Papan Asri saat ini yang memiiliki jarak $15 \mathrm{~km}$. Sedangkan untuk kebutuhan yang lebih besar, penduduk desa harus belanja ke kota Bumi yang berjarak $30 \mathrm{~km}$.

Pada saat itu, belum ada kendaraan umum dan masyarakat desa masih sangat minim sehinga mereka biasa berdagang maupun belanja ke pasar-pasar tersebut dengan berjalan kaki sebagian ada yang naik sepeda. Dari itulah maka terbentuklah pasar Semuli Raya di mana saat

\footnotetext{
${ }^{33}$ Karyo, Wawancara, Semuli Raya, 1 Oktober 2020.

${ }^{34}$ Ali, Wawancara, Semuli Raya, 25 Oktober 2020.
} 
itu masih berupa lahan kosong semak belukar. Namun saat ini pasar Semuli Raya sudah banyak mengalami kemajuan di segala bidang.

\section{Alasan Pedagang Meminjam Uang kepada Rentenir}

Banyak permasalahan dari pedagang kecil yang berada di pasar Semuli Raya yang juga dialami oleh para pedagang di pasar pada umumnya. Beberapa permasalahan yang dihadapi para pedagang kecil di pasar Semuli Raya adalah permodalan. Persoalan ini yang menjadikan pedagang kemudian berhubungan dengan rentenir. Mereka beralasan meminjam uang kepada rentenir karena terpaksa disebabkan permodalan yang menipis untuk menyambung hidup agar tetep bisa berdagang. Walaupun menyadari berat dan mengetahui meminjam kepada rentenir termasuk riba dan dilarang dalam agama. Tetapi kemudahan yang mereka dapatkan dari meminjam kepada rentenir adalah kemudahan dan tidak diperlukan persyaratan yang rumit. ${ }^{35}$

Pedagang tidak memahami apa itu rentenir, yang mereka tahu bahwa meminjam uang sudah selayaknya ada kelebihan dan bunga karena meminjam juga untuk dagang. Mereka meminjam kepada rentenir karena kehidupan yang semakin sulit, terlebih pada masa pandemik covid-19 sekarang yang mengakibatkan menurunnya jumlah konsumen sehingga banyak dagangan tidak laku. Agar mereka tetap dapat berdagang maka caranya meminjam modal yang tersedia dan mudah, dan ini hanya ada pada rentenir. ${ }^{36}$ Meminjam kepada rentenir mudah dan tidak berbelit, tidak diperlukan banyak persyaratan sebagaimana meminjam kepada lembaga keuangan dan perbankan. ${ }^{37}$

Dari pedagang yang telah diwawancara, seluruhnya melakukan pinjaman kepada rentenir karena keterpaksaan akibat kehabisan modal usaha mereka. Ada beberapa pedagang yang juga sudah berusaha untuk meminjam uang kepada sanak saudara, tetangga, dan lain sebagainya namun hasilnya nihil, maka mereka melakukan pinjam kepada rentenir. Ada juga pedagang yang langsung meminjam uang kepada rentenir diakibatkan para sanak saudara dan tetangga mereka sudah dapat dipastikan tidak akan memberikan pinjaman kepada mereka.

Dapat disimpulkan ada dua alasan para pedagang meminjam uang kepada rentenir untuk modal. Pertama, kemudahan dan prosesnya yang cepat, hanya bermodalkan kepercayaan pedagang tersebut sudah dapat menerima pinjaman uang dari rentenir. Kedua, kondisi keterpaksaan. Walaupun sudah berusaha untuk meminjam uang kepada saudara, kerabat terdekat, dan tetangga, para pedagang akhirnya meminjam uang kepada rentenir. Padahal sebagian dari pedagang mengetahui bahwa meminjam uang kepada rentenir termasuk riba.

\section{Dampak Praktik Rentenir terhadap Sosial Ekonomi dan Pendapatan Pedagang Pasar Semuli Raya}

Rente merupakan perjanjian pinjam meminjam uang disertai dengan bunga merupakan salah satu bentuk perjanjian yang dikenal oleh masyarakat Indonesia, dan hal ini dapat dikatakan telah membudaya. Namun, khusus bagi umat Islam perbuatan ini dikenal sebagai riba yang diharamkan menurut ajaran Islam sebagaimana ditegaskan dalam al-Quran.

\footnotetext{
${ }^{35}$ Supardi, Wawancara, Semuli Raya, 27 Oktober 2020.

${ }^{36}$ Kartini, Wawancara, Semuli Raya, 27 Oktober 2020.

${ }^{37}$ Salmah, Wawancara, Semuli Raya, 27 Oktober 2020.
} 
Praktik rente erat kaitannya dengan bunga karena adanya tambahan dari modal pokok pinjaman. Islam jelas telah melarang perbuatan yang mengandung unsur riba, seperti yang disampaikan Allah dalam firmannya surat Ali Imran ayat 130-131.

Perjanjian pinjam meminjam yang disertai bunga merupakan suatu bentuk perjanjian yang lahir berdasarkan atas kepakatan antara pemilik uang dan pihak peminjam. Perjanjian semacam ini, di satu pihak dikenal atau diperbolehkan baik dalam sistem Hukum Adat maupun dalam sistem Hukum Perdata, dan di lain pihak tidak ada larangan dalam Hukum Pidana (khususnya tindak pidana perbankan). Sehingga sangat keliru kalau seseorang yang meminjamkan uang dengan bunga dikatakan menjalankan praktik "bank gelap".

Dalam kasus rentenir yang dikenal oleh masyarakat sebenarnya bukan terjadi berdasarkan hukum akan tetapi hanyalah penyalagunaan yang sedang dihadapkan oleh orang tersebut. Hal ini dapat pula dikatakan sebagai penyalahgunaan kepercayaan seseorang untuk melakukan kegiatan yang berhubungan dengan kegiatan perputaran uang dalam lingkup secara mikro.

Yang terjadi di masyarakat kita khususnya masyarakat desa Semuli Raya Kecamatan Abung Semuli, kegiatan semacam rentenir sangat menunjang bagi masyarakat karena mampu membantu masyarakat yang keuangannya menipis. Sejalan dengan hasil wawancara terhadap salah satu warga di desa semuli Raya Kecamatan Abung Semuli.

Suwandi mengatakan bahwa dampak dari pihak rentenir menetapkan bunga pinjaman sangat tinggi, dan dampaknya sangat mengagetkan sekali karena disamaratakan, maksudnya yang meminjam kalau terlambat bayar langsung menyita barang-barang dan apabila si peminjam yang tidak mampu membayar akan menumbuhkan bunga di tengah masyarakat. Padahal bunga tersebut memiliki dampak yang signifikan terhadap masyarakat, baik dalam bidang ekonomi maupun sosial. ${ }^{38}$

Dampak negatif dari adanya rentenir di tengah masyarakat antara lain:

1. Timbulnya ketimpangan

Dampak dari berkembangnya rentenir adalah munculnya kelompok-kelompok yang cukup banyak menguasai sumber daya. Terjadinya ketimpangan yang cukup mencolok di masyarakat. Hal ini berakibat pada pola individualisme dan ketimpangan di masyarakat. ${ }^{39}$

2. Menimbulkan egoisme moral-spiritual

Institusi bunga merupakan sumber bahaya dan kejahatan. Bunga akan menyengsarakan dan menghancurkan masyarakat melalui pengaruhnya terhadap karakter manusia, di antaranya bunga menimbulkan perasaan cinta terhadap uang dan hasrat untuk mengumpulkan harta bagi kepentingannya sendiri tanpa mengindahkan peraturan dan peringatan Allah. ${ }^{40}$ Bunga menumbuhkan sikap egois, pelit, berwawasan sempit serta berhati batu. Seseorang yang membungakan uangnya akan cenderung bersikap tidak mengenal belas kasihan:

a. Bila si peminjam dalam kesulitan, maka asset apapun yang ada harus diserahkan untuk melunasi akumulasi bunga yang sudah berbunga lagi. Ia juga akan terdorong

\footnotetext{
${ }^{38}$ Suwandi, Wawancara, Semuli Raya, 27 Oktober 2020.

39 Muh. Al Juned, "Dampak Praktek Rentenir Terhadap Sosial Ekonomi di Kelurahan Gunung Sari Kec. Rappocini Semuli Raya” (Skripsi--UIN Alauddin, 2014), 41.

${ }^{40}$ Ibid., 43.
} 
untuk bersikap tamak, dan cenderung menjadi orang yang kikir.

b. Secara psikologis, praktik pembungaan uang juga dapat menjadikan seseorang malas untuk menginvestasikan dananya dalam sektor usaha. Hal ini terbukti pada krisis ekonomi yang melanda Indonesia baru-baru ini. Orang yang memiliki dana lebih baik tidur di rumah sambil menanti kucuran bunga pada akhir bulan, karena menurutnya sekalipun ia tidur uangnya bekerja dengan kecepatan 60\% hingga $70 \%$ per tahun. ${ }^{41}$

3. Menimbulkan kepongahan sosial-budaya

Secara sosial, institusi bunga merusak semangat berkhidmat kepada masyarakat. Orang akan enggan berbuat apapun kecuali yang memberi keuntungan bagi diri sendiri. Keperluan seseorang dianggap merupakan peluang bagi orang lain untuk meraup keuntungan. Kepentingan orang kaya dianggap bertentangan dengan kepentingan orang miskin. Masyarakat demikian tidak akan mencapai solidaritas dan kepentingan bersama untuk menggapai keberhasilan dan kesejahteraan. Cepat atau lambat, masyarakat demikian akan mengalami perpecahan. ${ }^{42}$

4. Riba dianggap curang dan eksploitatif

a. Mendapatkan suku bunga dari debitor berarti bahwa uang debitor diambil tanpa memberikan apapun sebagai imbalan. Ini tidak hanya menjadikan debitor kian buruk keadaannya, tapi juga gagal menciptakan kerja sama saling menguntungkan dan iktikad baik antara kreditor dan debitor.

b. Kreditor, di sisi lain, mendapatkan uang tanpa bekerja atau menanggung resiko apapun. Ini tidak adil, satu pihak dalam kontrak hasil finansial hanya berhak mendapatkan imbalan hasil jika pihak itu menanggung resiko.

c. Pembiayaan berbasis bunga cenderung meningkatkan kesenjangan kekayaan antara si kaya dan si miskin. ${ }^{43}$

5. Menimbulkan kezaliman ekonomi

Pembayaran angsuran bunga yang berat secara terus menerus terbukti telah merendahkan standar kehidupan masyarakat serta menghancurkan pendidikan anak-anak mereka. Kecemasan terus menerus peminjam juga mempengaruhi kehidupan pribadi dan keluarga peminjam, namun juga memperlemah perekonomian negara.

Dampak positif yang dapat dirasakan dari adanya pinjaman dari rentenir adalah:

1. Dalam kondisi mendesak, lembaga kredit dapat membantu kesulitan keuangan sementara.

2. Eksistensi lembaga keuangan informal dalam waktu yang relatif singkat dapat meningkatkan konsumsi dan prestasi masyarakat. ${ }^{44}$

Kegiatan rentenir, cara kerjanya sangat menunjang masyarakat. Hal inilah yang terjadi di kalangan masyarakat desa Semuli Raya Kecamatan Abung Semuli. Namun di samping kegiatannya yang sangat menunjang masyarakat terdapat pula dampak yang langsung

\footnotetext{
41 Ibid.

${ }^{42}$ M. Syafi'i Antonio, Bank Syariah dari Teori ke Praktik (Bandung: Linda Karya, 2007), 77.

${ }^{43}$ Daud Vicary Abdullah dan Keon Chee, Buku Pintar Keuangan Syariah (Jakarta: Zaman, 2012), 73.

${ }^{44}$ Juwita Fajar Hari, "Dampak Pinjaman Kredit Rentenir", 42.
} 
dirasakan oleh masyarakat. Hal ini diperjelas dengan berbagai keluhan-keluhan yang dialami oleh masyarakat ketika pembayaran tagihannya yang terlalu besar tingkat bunganya.

Kebanyakan masyarakat mendapatkan masalah dalam bermuamalah dengan rentenir, hal ini dapat dilihat ketika dalam pembayaran tagihan. Rentenir tidak segan-segan memakai orang bayaran untuk menagih pihak yang meminjam uang. Dampak tersebut yang dikeluhkan oleh pihak peminjam uang. Masyarakat yang tidak mampu membayar dan berimbas pada pendidikan anak-anaknya. Yang tidak punya uang langsung saja memberhentikan anaknya untuk tidak sekolah lagi karena fokus mencari uang untuk membayar penjaman ke rentenir. ${ }^{45}$

Hal ini sejalan dengan teori yang dikemukakan oleh Dale W Adam yang menyatakan bahwa rentenir adalah individu yang memberikan kredit jangka pendek, tidak menggunakan jaminan yang pasti, dan bunga relatif tinggi serta selalu berusaha melanggengkan kredit dengan nasabah. ${ }^{46}$ Maksud tidak menggunakan jaminan yang pasti adalah masyarakat yang melakukan peminjaman uang terhadap rentenir tidak serta merta diberikan kepastiaan pelunasannya dilakukan. Kapanpun pihak rentenir ingin menagih uangnya diperbolehkan.

\section{Kesimpulan}

Berdasarkan hasil penelitian, maka dapat ditarik kesimpulan bahwa alasan pedagang adalah dikarenakan proses peminjaman uang yang cepat, mudah, tidak harus memiliki barang berharga sebagai jaminan, nominal pinjaman tidak terlalu besar, hanya bermodalkan kepercayaan, dapat langsung menerima pinjaman uang walaupun karena keterpaksaan.

Praktik rente di kalangan masyarakat berdampak negatif terhadap ekonomi masyarakat. Praktik rente yang dilakukan di pedagang pasar Semuli Raya Kecamatan Abung Semuli menyebabkan perekonomian masyarakat sangat terganggu baik untuk kebutuhan sehari-hari bahkan berdampak pada pendidikan anak-anaknya.

\section{Daftar Rujukan}

Abdullah, Daud Vicary dan Keon Chee. Buku Pintar Keuangan Syariah. Jakarta: Zaman, 2012.

Antonio, M. Syafi'i. Bank Syariah dari Teori ke Praktik. Bandung: Linda Karya, 2007.

Deliarnov. Ekonomi Politik. Jakarta: Erlangga, 2006.

Departemen Pendidikan dan Kebudayaan, Kamus Besar Bahasa Indonesia. Jakarta: Balai Pustaka, 1995.

Dimyati, Khudzaifah. "Profil Praktek Pelepasan Uang (Rentenir) dalam Masyarakat Transisi”. Tesis--Universitas Diponegoro Semarang, 1997.

Gilarso. Pengantar Ilmu Ekonomi. Yogyakarta: t.p., 1991.

Hakim, Lukmanul. Prinsip-Prinsip Ekonomi Islam. Jakarta: Erlangga, 2012.

Hakim, Muhammad Aziz. Menguasai Pasar Mengeruk Untung. Jakarta: PT. Krisna Persada, 2005.

Hari, Juwita Fajar. "Dampak Pinjaman Kredit Terhadap Kesejahteraan Pedagang Pasar Tradisional dalam Tinjauan Ekonomi Islam”. Skripsi--IAIN Imam Bonjol, 2009.

Hosen, M. Nadrotuzaman dan AM. Hasan Ali. Kamus Populer Keuangan dan Ekonomi

${ }^{45}$ Dafa, Wawancara, Semuli Raya, 21 Desember 2019.

${ }^{46}$ Khudzaifah Dimyati, "Profil Praktek Pelepasan Uang”, 16. 
Syariah. Jakarta: PKES Publising, 2008.

Khoiri, Muhammad "Dampak Pinjaman Rentenir Terhadap Pendapatan Pedagang Pasar

Tradsional di Pasar Pagi Pulo Brayan Bengkel”. Skrips--UIN Sumatera Utara Medan, 2018.

Kotler, Philip. Manajemen Pemasaran, terj. Benyamin Molan, jilid 1. Jakarta: PT. Intan Sejati Klaten, 2005.

Mujahidin, Akhmad. Ekonomi Islam: Konsep, Instrument, Negara dan Pasar. Jakarta: Rajawali Press, 2014.

Nasution, Mustafa Edwin. Pengenalan Eksklusif Ekonomi Islam. Jakarta: Kencana, 2007.

Niswonger, C. Rollin, dkk. Prinsip-Prinsip Akuntansi, terj. Alfonsus Sirait. Jakarta: Erlangga, 1992.

Noor, Juliansyah. Metodelogi Penelitian: Skripsi, Tesis, Disertasi, dan Karya Ilmiah. Jakarta:

Kencana Prenada Media Group, 2011.

Prayitno, Rekso. Sistem Ekonomi dan Demokrasi Ekonomi. Jakarta: Bina Grafika, 2004.

Rais, Sasli. Pegadaian Syariah: Konsep dan Sistem Operasinal. Jakarta: UI-Press, 2006.

Siboro, Ilas Korwadi. "Analisis terhadap Fungsi Pinjaman Berbunga dalam Masyarakat

Rokan Hilir Kecamatan Bagan Sinembah Desa Bagan Batu", Jom Fisip, Volume 2, Nomor 1 (2015).

Sudarto, Aye. Etika Bisnis Islam. Metro: Purnama Jaya, 2019. . Peradaban Ekonomi Islam. Metro: Purnama Jaya, 2018.

Umar, Husen. Metode Riset Komunikasi Organisasi. Jakarta: Gramedia Pustaka Utama, 2005. Wijaya, Faried, dkk. Lembaga-Lembaga Keuangan dan Bank. Yogyakarta: BPFEY, 1999. https://www.pengertiandefinisi.com/pengertian-kegiatan-ekonomi-definisi-dan-jenis/ diakses pada tanggal 20 Oktober 2020.

https://www.google.com/amp/s/fersiamalia.wordpress.com/20111/11/28/uang-lembaga-

keuangan-dan-lembaga-keuangan-informal/amp diakses pada tanggal 31 Oktober 2019. http://medanbisnisdaily.com/news/read/2014/02/05/77027/rentenir_akan_tumbuh_pesat/\#VE

Pc6_I dWil diakses pada tanggal 10 Oktober 2019.

http://hukum.kompansiana.com/2012/07/20/rentenir-dan-lemahnya-hukum-perbankanindoneisa-472787.html diakses pada tanggal 05 oktober 2019. 